\title{
Butyrylcholinesterase genotype and enzyme activity in relation to Gulf War illness: preliminary evidence of gene-exposure interaction from a case-control study of 1991 Gulf War veterans
}

Lea Steele $^{1 *}$, Oksana Lockridge ${ }^{2}$, Mary M Gerkovich ${ }^{3}$, Mary R Cook $^{4}$ and Antonio Sastre ${ }^{5}$

\begin{abstract}
Background: Epidemiologic studies have implicated wartime exposures to acetylcholinesterase (AChE)-inhibiting chemicals as etiologic factors in Gulf War illness (GWI), the multisymptom condition linked to military service in the 1991 Gulf War. It is unclear, however, why some veterans developed GWI while others with similar exposures did not. Genetic variants of the enzyme butyrylcholinesterase (BChE) differ in their capacity for metabolizing AChE-inhibiting chemicals, and may confer differences in biological responses to these compounds. The current study assessed BChE enzyme activity and BChE genotype in 1991 Gulf War veterans to evaluate possible association of this enzyme with GWI.
\end{abstract}

Methods: This case-control study evaluated a population-based sample of 304 Gulf War veterans (144 GWI cases, meeting Kansas GWI criteria, and 160 controls). BChE enzyme activity levels and genotype were compared, overall, in GWI cases and controls. Potential differences in risk associated with cholinergic-related exposures in theater were explored using stratified analyses to compare associations between GWI and exposures in BChE genetic and enzyme activity subgroups.

Results: Overall, GWI cases and controls did not differ by mean BChE enzyme activity level or by BChE genotype. However, for the subgroup of Gulf War veterans with less common, generally less active, BChE genotypes (K/K, $\mathrm{U} / \mathrm{AK}, \mathrm{U} / \mathrm{A}, \mathrm{A} / \mathrm{F}, \mathrm{AK} / \mathrm{F})$, the association of wartime use of pyridostigmine bromide (PB) with $\mathrm{GWI}(\mathrm{OR}=40.00$, $p=0.0005)$ was significantly greater than for veterans with the more common $U / U$ and $U / K$ genotypes $(O R=2.68$, $p=0.0001)$.

Conclusions: Study results provide preliminary evidence that military personnel with certain BChE genotypes who used PB during the 1991 Gulf War may have been at particularly high risk for developing GWI. Genetic differences in response to wartime exposures are potentially important factors in GWI etiology and should be further evaluated in conjunction with exposure effects.

Keywords: Butyrylcholinesterase, Gulf War illness, Gulf War veterans, Pyridostigmine bromide, Gene-environment interaction

\footnotetext{
* Correspondence: Lea_Steele@baylor.edu

${ }^{1}$ Veterans Health Research Program, Baylor University Institute of Biomedical

Studies, One Bear Place \# 97261, Waco, TX 76798, USA

Full list of author information is available at the end of the article
} 


\section{Background}

Studies of veteran populations in the U.S. and other countries have consistently described a profile of chronic symptoms that afflict veterans of the 1991 Gulf War at significantly excess rates, compared to other veteran groups. This condition, commonly known as Gulf War illness (GWI), is estimated to affect between one fourth and one third of the nearly 700,000 U.S. veterans who served in the 1991 conflict [1-4]. Gulf War illness is characterized by multiple concurrent symptoms that include persistent headaches, cognitive difficulties, widespread pain, fatigue, gastrointestinal problems, and other chronic abnormalities-symptoms not accounted for by medical or psychiatric conditions routinely diagnosed in clinical practice. Longitudinal studies indicate that few veterans have recovered or substantially improved over time $[2,5,6]$.

Despite extensive research related to the health of Gulf War veterans, a detailed understanding of the specific nature and causes of GWI has not yet been conclusively established. Diverse biological alterations have been described in veterans with Gulf War illness compared to healthy controls, including significant differences in brain structure and function [7-10] as well as autonomic [11-13], immune [14-17], and endocrine [18,19] parameters. Epidemiologic studies of Gulf War veterans consistently indicate that GWI is not associated with combat stressors, when effects of other wartime exposures are taken into account, and that rates of psychiatric illness associated with the brief 1991 conflict are substantially lower than for other wars $[2,20,21]$.

A variety of potentially hazardous chemicals encountered by some Gulf War military personnel have been suggested as causes or contributors to GWI. These include multiple exposures with the potential to cause adverse neurological effects, including low-level exposure to chemical nerve agents, use of pyridostigmine bromide (PB) pills given prophylactically as a protective measure against nerve agents, and extensive use of pesticides. [2,21-23].

Few measurements were made during the war that documented the levels and concentrations of exposures experienced by individual veterans. However, useful information on deployment-related exposures has been provided by government investigations utilizing a variety of methods, including extensive command and field interviews, record reviews, event and exposure simulations, and modeling efforts [2]. Estimates provided by the Department of Defense (DOD) indicate that about 100,000 U.S. military personnel were potentially exposed, in March 1991, to low levels of the nerve agents sarin and cyclosarin in connection with demolitions at a large Iraqi munitions compound near Khamisiyah, Iraq [24]. Government reports also indicate that about half of American ground troops took PB tablets in varying amounts, and that military personnel used a wide range of pesticides and insect repellants in different combinations, often at excessive levels [22,23].

Sarin and cyclosarin are organophosphate compounds, $\mathrm{PB}$ is a carbamate compound, and the many pesticides used by military personnel in the Gulf War included a variety of both organophosphates and carbamates. These chemicals are acetylcholinesterase (AChE) inhibitors; that is, their chemical action interferes with breakdown of the neurotransmitter acetylcholine. These compounds can be acutely toxic, even fatal, at sufficiently high doses. But their long-term effects, particularly in relation to repeated, lower-dose exposures, are less well understood. Epidemiologic studies of Gulf War veterans consistently indicate that veterans who report using $\mathrm{PB}$ and pesticides have significantly higher rates of GWI than veterans who did not use these compounds in theater [21,25-27].

An important question concerning GWI relates to why some personnel developed chronic symptoms after the war while others with similar wartime experiences and exposures remained healthy. One possibility is that vulnerability to certain deployment-related exposures differed as a result of individual variability in the biological processes that neutralize these exposures and confer protection from acute and/or chronic adverse effects. Recent reports from both the federal Research Advisory Committee on Gulf War Veterans' Illnesses [20] and the Institute of Medicine [4] have suggested that genetic factors may have played a role in the development of GWI and have urged additional research to evaluate this possibility.

Acetylcholinesterase-inhibiting chemical exposures interact with a variety of circulating enzymes in humans, including two cholinesterases-butyrylcholinesterase (BChE) and $\mathrm{AChE}$. Butyrylcholinesterase is present at more than 10 times the level of AChE in whole blood, but its physiological functions are not completely understood. It is known to provide protection from adverse effects of carbamates, organophosphates, and other chemicals by acting as a scavenger, binding them molecule-for-molecule, thereby sparing circulating levels of $\mathrm{AChE}$ [28].

There is one gene for $\mathrm{BChE}$, located on chromosome $3 \mathrm{q} 26$, with multiple nucleotide variations identified at this locus [28]. The wild type " $U$ " allele is most common, followed by the K, A, and F mutations. The less common variants are associated, on average, with lower enzyme activity levels and/or binding affinity for AChE-inhibiting compounds, rendering individuals especially sensitive to a number of chemicals [28-30]. Individuals who are AA homozygotes, for example, experience prolonged apnea and paralysis - up to two hours-if given the muscle relaxant succinylcholine for surgery at doses that normally act only for several minutes [30]. Limited evidence also suggests that some $\mathrm{BChE}$ genetic variants may be more 
vulnerable to adverse effects of AChE inhibitors, including $\mathrm{PB}[28,31]$.

We report here on results from a case-control study that assessed BChE genotype and enzyme activity in veterans of the 1991 Gulf War. Data for the study were collected in 2001 in connection with a multipart project that evaluated deployment experiences, genetic variability, and autonomic nervous system function in veterans of the 1991 Gulf War.

\section{Methods}

\section{Study design and participants}

The study utilized a case-control design to evaluate BChE activity and genotype in relation to GWI and deployment characteristics in a population-based sample of 304 Gulf War veterans. Detailed information on the study sample and data collection have previously been described [21]. Study participants included 144 GWI cases and 160 controls, with cases defined according to Kansas GWI criteria [1]. Briefly, the Kansas GWI case definition requires that veterans endorse moderately severe or multiple chronic symptoms in at least three of six defined symptom domains. Veterans are excluded as GWI cases if they report being diagnosed with any from a list of chronic medical conditions that might account for their symptoms, or severe psychiatric conditions that might preclude their ability to accurately report symptoms. Veteran controls had insufficient symptoms to meet GWI case criteria, and reported no exclusionary medical or psychiatric diagnoses. The study questionnaire also included symptom questions that allowed identification of veterans who met case criteria for "chronic multisymptom illness (CMI)," as defined by Fukuda et al. [32] at the U.S. Centers for Disease Control and Prevention, sometimes referred to as the "CDC" case definition.

In addition to symptoms and medical conditions, veterans provided information on their demographic and military characteristics, on 19 experiences and exposures potentially encountered during their 1990-1991 deployment, and on the general locations in which they served in the Gulf War theater of operations.

In conducting this research, investigators complied with all applicable U.S. regulations regarding the protection of human subjects. The study protocol was approved by Institutional Review Boards of the Kansas Department of Health and Environment and Midwest Research Institute, and by the Army's Office of Human Research Protections. Veteran participants gave both oral and written informed consent prior to enrolling in the study.

\section{Laboratory methods}

Two $9.5 \mathrm{~mL}$ tubes of blood were collected from each veteran to determine $\mathrm{BChE}$ enzyme activity level and genotype. Phenotype was determined by measuring serum enzyme activity with benzoylcholine in $\mathrm{Na} / \mathrm{K}$ phosphate buffer, as previously described [33]. Inhibition of activity by dibucaine was used to identify "atypical" (A) and fluoride-resistant (F) phenotypes. Where unusual dibucaine inhibition levels were observed, inhibition by $50 \mu \mathrm{M}$ sodium fluoride was measured to distinguish between UA, UF, AF, FF, and FS phenotypes $[34,35]$.

DNA was isolated and amplified by polymerase chain reaction, followed by restriction enzyme digestion, to determine genotype at the $\mathrm{BChE}$ polymorphic site Ala/Thr 539 (K variant). Amplification created a Mae III restriction site when the K-variant ACA codon (Thr 539) was present [35]. DNA from samples that phenotyped as heterozygous for the BChE F variant were amplified and sequenced to determine which of three reported DNA mutations were responsible for the fluoride resistance [36,37]. Similarly, DNA from samples that phenotyped as heterozygous for the atypical variant (Asp70Gly) were amplified and sequenced to confirm the presence of the codon for Gly70 [38]. Laboratory analyses were performed by technicians who had no information on characteristics of veterans' health or military service.

\section{Data analyses}

Mean BChE enzyme activity levels were determined for each genetic type identified in the sample, for GWI cases and controls, and for demographic subgroups. Mean values were compared using Student's t-tests. Proportional comparisons between veteran subgroups were assessed using chi-square statistics except as noted.

Associations between GWI and each "cholinergic" exposure queried for the study (that is, exposures with the potential for cholinergic effects) were evaluated in veteran subgroups defined by BChE activity and genotype. Comparably-sized BChE activity subgroups were defined according to whether veterans' $\mathrm{BChE}$ activity level, measured at the time of the study, was equal to/above vs. below the median level for the sample as a whole (1.09 $\mu$ moles benzoylcholine per minute per $\mathrm{mL}$ serum). Prevalence odds ratios (ORs) for GWI/exposure associations were calculated separately for BChE activity subgroups and compared across strata.

Similar analyses compared associations between GWI and exposures in BChE genetic subgroups. Because of the relatively small number of individuals with each of the less common, and generally less active, BChE genotypes $(\mathrm{K} / \mathrm{K}, \mathrm{U} / \mathrm{AK}, \mathrm{U} / \mathrm{A}, \mathrm{A} / \mathrm{F}, \mathrm{AK} / \mathrm{F})$ in the sample, veterans with these genotypes were combined into a single $\mathrm{BChE}$ "less common variants" (BChE-LCV) subgroup, for comparison to veterans with $\mathrm{U} / \mathrm{U}$ and $\mathrm{U} / \mathrm{K}$ genotypes. Prevalence odds ratios (ORs) for GWI/exposure associations were calculated separately for $\mathrm{BChE}$ genetic subgroups and compared across strata. 
To assess possible confounding issues that might underlie the gene-exposure interaction identified by the study, post-hoc analyses were conducted to determine whether characteristics and exposures reported by the BChE-LCV genetic subgroup differed from those of other veterans in the study. Additional post-hoc analyses assessed whether the identified interaction might have been an anomaly of the Kansas GWI case criteria used for the study. For this assessment, symptom data were used to "reassign" case/ control status for all 304 veteran subjects, with case status determined using the CMI criteria of Fukuda et al. [32]. Prevalence odds ratios (ORs) were again calculated separately for BChE genetic subgroups to assess the association of illness with exposure in CMI cases and controls. All statistical analyses were conducted using SAS statistical software, version 9.2 [39].

\section{Results}

\section{Study population}

Health, demographic, and military characteristics of the study population are described in detail elsewhere [21]. Gulf War illness cases were similar to controls with respect to sex (cases: $8 \%$ female; controls: $7 \%$ female; $\mathrm{p}=$ 0.80 ) and age (mean age cases: 37.4 ; mean age controls: $36.9 ; \mathrm{p}=0.53$ ) at study intake, but differed significantly by race (cases: $83 \%$ white; controls $94 \%$ white; $\mathrm{p}=0.01$ ).

\section{BChE activity and genotype in Gulf War veterans}

Mean BChE enzyme activity levels are shown in Table 1 for all veterans combined, for each BChE genotype in the sample, for demographic subgroups, and for GWI cases and controls. As expected, the BChE-LCV subgroup of veterans exhibited, on average, significantly lower BChE activity levels than veterans with $U / U$ and $\mathrm{U} / \mathrm{K}$ genotypes. Enzyme activity did not vary significantly by race or by age. Similar to the general population [40], female Gulf War veterans had significantly lower BChE activity than males. The mean BChE activity level of GWI cases was nearly identical to that of controls.

When the sample was evaluated overall, the BChE genetic profiles of GWI cases and controls were also nearly identical (Table 2). That is, no significant association between GWI case status and BChE genotype was found, either in the distribution of specific BChE variants or in the overall proportion of cases and controls with less common BChE genotypes.

\section{Association between GWI and exposures in relation to BChE activity and genotype}

We assessed whether BChE variability played a role in observed associations between GWI and deployment exposures that potentially had cholinergic effects. This included all variables related to pesticide exposures and $\mathrm{PB}$ use, and one variable possibly related to low-level
Table 1 Butyrylcholinesterase (BChE) enzyme activity in Gulf War veterans

\begin{tabular}{|c|c|c|}
\hline & $\mathbf{n}$ & $\begin{array}{l}\text { BChE mean } \\
\text { (SD) activity }\end{array}$ \\
\hline All veterans in study & 304 & $1.10(0.26)$ \\
\hline \multicolumn{3}{|l|}{ BChE genotype } \\
\hline U/U & 189 & $1.19(0.24)$ \\
\hline $\mathrm{U} / \mathrm{K}$ & 87 & $1.01(0.21)$ \\
\hline K/K & 13 & $0.80(0.15)$ \\
\hline U/AK & 10 & $0.76(0.18)$ \\
\hline U/A & 3 & $1.03(0.12)$ \\
\hline$A / F$ & 1 & 0.92 \\
\hline AK/F & 1 & 0.69 \\
\hline Common variants combined ( $U / U$ and $U / K)$ & 276 & $1.13(0.24)$ \\
\hline $\begin{array}{l}\text { Less common variants combined } \\
(K / K, U / A K, U / A, A / F, A K / F)\end{array}$ & 28 & $0.81(0.17)^{\uparrow}$ \\
\hline \multicolumn{3}{|l|}{ Race } \\
\hline White & 265 & $1.10(0.26)$ \\
\hline Black & 26 & $1.07(0.24)$ \\
\hline Other & 8 & $1.12(0.23)$ \\
\hline \multicolumn{3}{|l|}{ Sex } \\
\hline Male & 282 & $1.11(0.25)$ \\
\hline Female & 22 & $0.95(0.26)^{\uparrow \uparrow}$ \\
\hline \multicolumn{3}{|l|}{ Age at time of study } \\
\hline 29-39 & 189 & $1.10(0.25)$ \\
\hline $40-49$ & 77 & $1.14(0.27)$ \\
\hline $50+$ & 38 & $1.05(0.23)$ \\
\hline \multicolumn{3}{|l|}{ Gulf War illness case status } \\
\hline Gulf War illness cases & 144 & $1.10(0.24)$ \\
\hline Gulf War veteran controls & 160 & $1.10(0.27)$ \\
\hline
\end{tabular}

$\mathrm{BChE}=$ butyrylcholinesterase, $\mathrm{SD}=$ standard deviation.

${ }^{*}$ Mean enzyme activity expressed in $\mu$ moles benzoylcholine hydrolyzed per minute per $\mathrm{mL}$ of serum.

${ }^{\top}$ Mean enzyme activity differs significantly from $\mathrm{U} / \mathrm{U}$ and $\mathrm{U} / \mathrm{K}(\mathrm{p}<0.001)$.

${ }^{\uparrow}$ Mean enzyme activity differs significantly from males $(p=0.003)$.

nerve agent exposure (hearing chemical alarms). No significant differences were identified between Gulf War veteran subgroups defined by BChE enzyme activity. That is, associations between GWI and exposures were similar in veterans with lower versus higher BChE enzyme activity measured at the time of the study (results not shown in tables).

In evaluating associations between GWI and cholinergic exposures in relation to $\mathrm{BChE}$ genotype, there were no significant differences between $\mathrm{U} / \mathrm{U}$ and $\mathrm{U} / \mathrm{K}$ genotype subgroups (Table 3). For the BChE-LCV subgroup, however, GWI risk was dramatically elevated for veterans who reported taking $\mathrm{PB}$ pills during deployment ( $\mathrm{OR}=40.00, \mathrm{p}=0.0005$, Fisher's exact test). Use of $\mathrm{PB}$ pills was also associated with GWI among veterans with 
Table 2 Distribution of butyrylcholinesterase genotype in Gulf War illness cases and controls

\begin{tabular}{|c|c|c|c|c|c|c|}
\hline \multirow[b]{2}{*}{ BChE genotype } & \multicolumn{2}{|c|}{$\begin{array}{c}\text { Total sample } \\
(n=304)\end{array}$} & \multicolumn{2}{|c|}{$\begin{array}{c}\text { GWI cases } \\
(n=144)\end{array}$} & \multicolumn{2}{|c|}{$\begin{array}{l}\text { Controls } \\
(n=160)\end{array}$} \\
\hline & $\mathrm{n}$ & (\%) & $\bar{n}$ & (\%) & $n$ & (\%) \\
\hline $\mathrm{U} / \mathrm{U}$ & 189 & $(62 \%)$ & 89 & $(62 \%)$ & 100 & $(62 \%)$ \\
\hline$U / K$ & 87 & $(29 \%)$ & 41 & $(28 \%)$ & 46 & $(29 \%)$ \\
\hline $\mathrm{K} / \mathrm{K}$ & 13 & $(4 \%)$ & 7 & $(5 \%)$ & 6 & $(4 \%)$ \\
\hline U/AK & 10 & $(3 \%)$ & 5 & (3\%) & 5 & (3\%) \\
\hline U/A & 3 & $(1 \%)$ & 1 & $(<1 \%)$ & 2 & $(1 \%)$ \\
\hline$A / F$ & 1 & $(<1 \%)$ & 0 & $(0 \%)$ & 1 & $(<1 \%)$ \\
\hline AK/F & 1 & $(<1 \%)$ & 1 & $(<1 \%)$ & 0 & $(0 \%)$ \\
\hline $\begin{array}{l}\text { Less common } \\
\text { variants combined } \\
\text { (K/K, U/AK, U/A. A/F, AK/F) }\end{array}$ & 28 & (9\%) & 14 & $(10 \%)$ & 14 & (9\%) \\
\hline
\end{tabular}

$\mathrm{BChE}=$ butyrylcholinesterase, $\mathrm{GWI}=$ Gulf War illness .

$\mathrm{U} / \mathrm{U}$ and $\mathrm{U} / \mathrm{K}$ genotypes, but to a much lesser degree $(\mathrm{OR}=2.68$ for $\mathrm{U} / \mathrm{U}$ and $\mathrm{U} / \mathrm{K}$ subgroups combined, $\mathrm{p}=$ $0.0001)$. The difference between ORs for veterans in the BChE-LCV subgroup and veterans with $\mathrm{U} / \mathrm{U}$ and $\mathrm{U} / \mathrm{K}$ genotypes was statistically significant $(\mathrm{p}=0.019$, BreslowDay test for homogeneity of ORs), indicating a significant interaction between exposure and $\mathrm{BChE}$ genotype. This interaction indicates a substantially increased risk for GWI for the subgroup of Gulf War veterans with less common BChE genotypes (K/K, U/AK, U/A, A/F, and AK/F) who used PB during deployment.

No other significant interactions were identified in relation to BChE genotype. That is, the association of GWI with veteran-reported use of pesticides and experiences possibly linked to chemical weapons exposures did not differ among veterans in the $\mathrm{U} / \mathrm{U}, \mathrm{U} / \mathrm{K}$, and $\mathrm{BChE}-\mathrm{LCV}$ genetic subgroups.

The striking interaction between $\mathrm{BChE}$ genotype and the use of $\mathrm{PB}$ pills during deployment prompted additional evaluations to assess whether the observed effect might have been the result of other factors, such as an inconsistency in the pattern of exposures reported by $\mathrm{BChE}$ variants, or an anomaly of the GWI case definition used for the study. Overall, veterans in the BChELCV subgroup were nearly identical to veterans in the other two subgroups with respect to sex, age, education, rank, branch of service, deployment locations, and proportion reporting deployment exposures. For example, $58 \%$ of veterans in the BChE-LCV subgroup reported using $\mathrm{PB}$ pills, compared to $57 \%$ of those with $\mathrm{U} / \mathrm{U}$ and $\mathrm{U} / \mathrm{K}$ genotypes $(\mathrm{p}=0.93)$. Similarly, $19 \%$ of the $\mathrm{BChE}-$ LCV subgroup reported wearing uniforms treated with pesticides, compared to $18 \%$ of veterans with $\mathrm{U} / \mathrm{U}$ and $\mathrm{U} / \mathrm{K}$ genotypes $(\mathrm{p}=0.90)$.

Additional analyses indicated that the elevated GWI risk associated with the use of $\mathrm{PB}$ by the $\mathrm{BChE}-\mathrm{LCV}$ subgroup of veterans was not uniquely tied to the Kansas GWI case definition (Table 4). A similar pattern was observed when case status was reassigned, based on the chronic multisymptom illness criteria of Fukuda et al. [32], yielding 187 cases and 117 controls. Using either case definition, chronic symptomatic illness was significantly associated with use of PB pills for the sample as a whole. However, the PB-illness association was substantially more pronounced in the subgroup of veterans with less common, and generally slower acting $\mathrm{BChE}$ genotypes (K/K, U/AK, U/A, A/F, and AK/F).

Table 3 Association of Gulf War illness with exposures with potential cholinergic effects, by butyrylcholinesterase genetic subgroup

\begin{tabular}{|c|c|c|}
\hline \multicolumn{3}{|c|}{ Butyrylcholinesterase genetic subgroup } \\
\hline $\begin{array}{c}\text { U/U homozygotes } \\
\text { ( } n=89 \mathrm{GWI} \text { cases, } 100 \text { controls })\end{array}$ & $\begin{array}{c}\text { U/K heterozygotes } \\
\text { ( } n=41 \mathrm{GWI} \text { cases, } 46 \text { controls) }\end{array}$ & $\begin{array}{l}\text { Less common BChE variants } \\
(\mathrm{K} / \mathrm{K}, \mathrm{U} / \mathrm{AK}, \mathrm{U} / \mathrm{A}, \mathrm{A} / \mathrm{F}, \mathrm{AK} / \mathrm{F}) \\
\text { ( } \mathrm{n}=14 \mathrm{GWI} \text { cases, } 14 \text { controls) }\end{array}$ \\
\hline
\end{tabular}

\begin{tabular}{|c|c|c|c|c|c|c|c|c|c|}
\hline \multirow[b]{2}{*}{ Experience/exposure } & & & \\
\hline & $\begin{array}{l}\% \text { cases } \\
\text { exposed }\end{array}$ & $\begin{array}{l}\% \text { controls } \\
\text { exposed }\end{array}$ & $\mathrm{OR}^{*}(95 \%$ C.I. $)$ & $\begin{array}{l}\% \text { cases } \\
\text { exposed }\end{array}$ & $\begin{array}{c}\% \text { controls } \\
\text { exposed }\end{array}$ & OR $^{*}$ (95\% C.I.) & $\begin{array}{l}\% \text { cases } \\
\text { exposed }\end{array}$ & $\begin{array}{l}\% \text { controls } \\
\text { exposed }\end{array}$ & OR $^{*}(95 \%$ C.I.) \\
\hline $\begin{array}{l}\text { Took PB (pyridostigmine } \\
\text { bromide) pills }\end{array}$ & $67 \%$ & $48 \%$ & $2.25(1.23-4.11)$ & $74 \%$ & $41 \%$ & $3.98(1.57-10.1)$ & $92 \%$ & $23 \%$ & $40.0^{\uparrow}(3.58-447)$ \\
\hline $\begin{array}{l}\text { Wore uniforms treated } \\
\text { with pesticides }\end{array}$ & $22 \%$ & $8 \%$ & $3.07(1.27-7.44)$ & $37 \%$ & $11 \%$ & $4.92(1.59-15.2)$ & $29 \%$ & $8 \%$ & $4.80(0.46-50.2)$ \\
\hline $\begin{array}{l}\text { Used pesticide cream } \\
\text { or spray on skin }\end{array}$ & $55 \%$ & $31 \%$ & $2.75(1.50-5.02)$ & $62 \%$ & $28 \%$ & $4.23(1.71-10.5)$ & $50 \%$ & $43 \%$ & $1.33(0.31-5.91)$ \\
\hline $\begin{array}{l}\text { Living area sprayed } \\
\text { with pesticides }\end{array}$ & $21 \%$ & $18 \%$ & $1.23(0.59-2.57)$ & $24 \%$ & $17 \%$ & $1.47(0.51-4.29)$ & $21 \%$ & $14 \%$ & $1.64(0.23-11.7)$ \\
\hline $\begin{array}{l}\text { Heard chemical } \\
\text { alarms sounded }\end{array}$ & $57 \%$ & $57 \%$ & $1.02(0.57-1.82)$ & $62 \%$ & $44 \%$ & $2.00(0.84-4.79)$ & $64 \%$ & $50 \%$ & $1.80(0.40-8.18)$ \\
\hline
\end{tabular}

$\mathrm{BChE}=$ butyrylcholinesterase, $\mathrm{GWI}=$ Gulf War illness, $\mathrm{OR}=$ prevalence odds ratio, C.I. = confidence interval.

*OR compares GWI cases with controls within each genetic subgroup.

${ }^{\uparrow}$ OR for veterans with less common BChE variant genotypes differs significantly from OR for veterans with $\mathrm{U} / \mathrm{U}$ and $\mathrm{U} / \mathrm{K}$ genotypes, $\mathrm{p}=0.019$. 
Table 4 Association of pyridostigmine bromide use with chronic illness in BChE subgroups: evaluation using two case definitions

\begin{tabular}{|c|c|c|c|c|c|c|c|c|c|}
\hline \multirow[b]{3}{*}{ Case definition } & \multirow{2}{*}{\multicolumn{3}{|c|}{$\begin{array}{l}\text { Use of PB by all Gulf War veterans } \\
\qquad(n=304)\end{array}$}} & \multicolumn{6}{|c|}{ Use of PB by butyrylcholinesterase genetic subgroups } \\
\hline & & & & \multicolumn{3}{|c|}{$\begin{array}{l}\text { Common } B C h E \text { variants } \\
(U / U \text { and } U / K)(n=276)\end{array}$} & \multicolumn{3}{|c|}{$\begin{array}{l}\text { Less common } B C h E \text { variants } \\
(K / K, U / A K, U / A, A / F, A K / F)(n=28)\end{array}$} \\
\hline & $\begin{array}{l}\% \text { cases } \\
\text { exposed }\end{array}$ & $\begin{array}{c}\% \text { controls } \\
\text { exposed }\end{array}$ & OR (95\% C.I.) & $\begin{array}{l}\% \text { cases } \\
\text { exposed }\end{array}$ & $\begin{array}{l}\% \text { controls } \\
\text { exposed }\end{array}$ & OR (95\% C.I.) & $\begin{array}{l}\% \text { cases } \\
\text { exposed }\end{array}$ & $\begin{array}{l}\% \text { controls } \\
\text { exposed }\end{array}$ & OR (95\% C.I.) \\
\hline $\begin{array}{l}\text { GWI } \\
\text { (Kansas case definition) }^{*}\end{array}$ & $72 \%$ & $44 \%$ & $3.21(1.97-5.24)$ & $69 \%$ & $46 \%$ & $2.68(1.62-4.44)$ & $92 \%$ & $23 \%$ & $40.00(3.58-447)$ \\
\hline 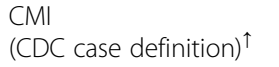 & $63 \%$ & $46 \%$ & $1.99(1.23-3.22)$ & $62 \%$ & $49 \%$ & $1.73(1.05-2.84)$ & $78 \%$ & $22 \%$ & $11.37(1.65-78.4)$ \\
\hline
\end{tabular}

$\mathrm{BChE}=$ butyrylcholinesterase, $\mathrm{PB}=$ pyridostigmine bromide, $\mathrm{CDC}=$ U.S. Centers for Disease Control and Prevention, OR $=$ prevalence odds ratio, $\mathrm{C} . \mathrm{I} .=$ confidence interval.

"Gulf War illness, as defined in Steele [1].

${ }^{\uparrow}$ Chronic multisymptom illness, as defined in Fukuda et al. [32].

\section{Discussion}

More than 23 years after the cease fire that ended Operation Desert Storm in 1991, our understanding of the specific factors that led to GWI remains incomplete. The present study provides the first direct evidence suggesting that interaction between genetic factors and a chemical exposure associated with Gulf War service may have contributed to the development of GWI. Specifically, the subgroup of Gulf War veterans in our study with less common, and generally less active, genetic variants of the enzyme $\mathrm{BChE}$ were at substantially increased risk for GWI if they took PB pills during deployment. This genetic subgroup constituted $9 \%$ of the veterans in our sample, and included all homozygous carriers of the $\mathrm{BChE} \mathrm{K}$ allele and heterozygous carriers of BChE A and $\mathrm{F}$ alleles. The identified interaction of BChE genotype with veterans' use of $\mathrm{PB}$ was a singular observation and requires corroboration in other veteran groups. However, this initial finding comes from a representative sample of Gulf War veterans, was highly significant, and was not explainable by study factors such as differential reporting of PB use or how GWI cases were defined.

This study therefore provides a foundation and model for an expanded investigation of gene-exposure interactions that potentially explain why some military personnel developed chronic illness in connection with Gulf War service while others, with similar deployment experiences and exposures, remained healthy. The association of GWI with $\mathrm{BChE}$ genotype was specific to veterans who reported using $\mathrm{PB}$ in our sample, and did not occur in connection with other wartime experiences like hearing chemical alarms and using different types of pesticides. Multiple genes can potentially contribute to differences in individual responses to cholinesterase inhibitors and other chemical exposures $[41,42]$. It is therefore possible that other genetic factors, such as polymorphisms of the paraoxonase (PON1) enzyme, might have played a role in the development of chronic illness in connection with Gulf War exposures.
Genetic variability in biological processes that neutralize $\mathrm{AChE}$ inhibitors has long been hypothesized to underlie differences in vulnerability to these compounds-in Gulf War veterans and in other exposed populations $[2,28,43,44]$. Although this is the first study to demonstrate a specific gene-exposure interaction in the risk for GWI, our findings are consistent with preliminary indications that unanticipated effects of Gulf War exposures may be linked to $\mathrm{BChE}$ genetic variability.

A 1995 case report described the experience of an Israeli soldier who developed severe symptoms when taking PB during the Gulf War at the recommended dosage (30 mg., three times per day) [31]. This soldier was found to be homozygous for the BChE A allele, and had a history of post-anesthesia apnea. Further investigation revealed that his serum BChE had only one-third normal activity, and very poor binding capacity for carbamates, including PB. Later, results from a DODsponsored study described in a federal project report suggested that BChE genotype may be associated with chronic symptoms in Nebraska Gulf War veterans [45]. Investigators determined $\mathrm{BChE}$ allele frequencies in 226 Gulf War veterans. Of 11 carriers of the A or F alleles, eight (73\%) had previously identified themselves as GWI "cases," suggesting a potential link between GWI and BChE variants.

Our general finding that mean $\mathrm{BChE}$ enzyme activity, measured at the time of the study, did not differ between GWI cases and controls parallels results from two previous studies [46,47]. However, a 2000 study indicated that BChE activity was significantly higher in 152 British Gulf War veterans with health concerns, compared to age and sex-matched individuals in the general population [48].

Variability in PON1 has also been suggested as a possible contributing factor to GWI. Four studies have reported on one or more PON1-related variables in relation to Gulf War service, yielding a somewhat mixed picture. The first, studying a Navy Seabees unit, reported that the 12 veterans with the most severe symptomatic 
illness were significantly more likely to have low PON1 type $Q$ arylesterase activity [46]. Two larger studies of British Gulf War veterans indicated that PON1 paraoxon activity was significantly lower in ill Gulf War veterans, overall, than comparison groups [48,49]. A more recent study of Iowa Gulf War veterans reported no associations with PON1 activity [47]. None of these studies, however, looked specifically at the question of whether associations between GWI and exposures differed with BChE or PON1genotype or phenotype.

\section{BChE in other exposed populations and in animal models}

The physiological functions of BChE are not well understood. Enzyme activity varies with BChE genotype, as demonstrated here, but is also temporarily reduced by certain drugs and environmental exposures. Although BChE genotype has previously been hypothesized to contribute to differences in susceptibility to adverse effects of cholinergic drugs and pesticides [28], few studies have evaluated BChE-associated risk in exposed populations. A 1996 study reported that "non-usual" BChE variants were significantly overrepresented among Brazilian farmers exposed to carbamate and organophosphate pesticides who exhibited mild signs of poisoning [50]. Related findings, from a more recent assessment of pesticideexposed farm workers, indicate that of 256 candidate single nucleotide polymorphisms (SNPs) in 30 genes potentially related to pesticide metabolism, the strongest correlates of reduced cholinesterase activity, over four time points, were two SNPs in the BChE gene [51].

Studies in several animal models also suggest a role for $\mathrm{BChE}$ in providing a protective biological response to $\mathrm{PB}[52,53]$. This includes findings that delayed central nervous system effects resulting from low-dose PB exposure occurred only in a genetic strain of rats with reduced BChE activity levels, not in a standard strain with normal BChE activity [54,55]. Additional insights regarding $\mathrm{BChE}$ activity in the brain come from studies suggesting that $\mathrm{BChE}$ has physiological actions in addition to its scavenging function. These include indications that BChE becomes biologically active in the brain under conditions in which acetylcholine is elevated, acting directly to reduce acetylcholine levels [56-58].

\section{Current BChE findings in context}

Several aspects of our findings deserve emphasis. First, the association between BChE genotype and GWI was not identified when all Gulf War veterans were evaluated together, but was only apparent in relation to $\mathrm{PB}$ use. This underscores the importance of assessing risk factors for GWI, including genetic risk factors, in appropriate subgroups. It also illustrates an important principle that is too often overlooked: genetic polymorphisms that produce reduced capacity to neutralize specific chemicals would generally not be expected to produce health consequences for individuals who are not exposed to those chemicals. It is therefore essential that studies whose purpose is to assess genetic factors in relation to GWI carefully evaluate those associations in connection with relevant exposures.

It is important to note that GWI was also associated with $\mathrm{PB}$ use in veterans with the common $\mathrm{U} / \mathrm{U}$ and $\mathrm{U} / \mathrm{K}$ genotypes in our sample, although the association was not as strong as in the BChE-LCV subgroup. This indicates that $\mathrm{PB}$ was a risk factor for GWI for reasons other than the apparent genetic vulnerability identified in this study. As detailed in a 2008 federal committee report, Gulf War Illness and the Health of Gulf War Veterans, PB is the most consistently-identified risk factor for GWI across all epidemiologic studies that adjusted for effects of concurrent wartime exposures [2]. This broader role for PB as a risk factor for GWI is supported by identification of dose-response effects in several studies [25,26,59], and by studies linking PB use during the Gulf War to brain and hypothalamic-pituitary-adrenal alterations in Gulf War veterans evaluated many years later $[9,18,19]$.

The association of PB with GWI differed by BChE genotype, but was not associated with BChE enzyme activity measured at the time of the study. While genetic type is the most sustained correlate of BChE activity over time, it is just one factor that potentially contributed to reduced $\mathrm{BChE}$ activity levels in theater. Independent of genotype, it is likely that BChE activity levels were reduced, to varying degrees, among some Gulf War personnel in theater, particularly during periods of sustained exposure to pesticides, $\mathrm{PB}$, and other cholinesterase inhibitors. Such "situational" reductions in BChE activity might have rendered veterans vulnerable to developing chronic symptoms via mechanisms similar to those that contributed to GWI in the BChE-LCV subgroup of veterans.

Our finding of a significant interaction between $P B$ and BChE genotype in the risk for GWI can only be considered preliminary, since it has not been evaluated in other veteran groups. If corroborated, this interaction would apply to only a subgroup of veterans who developed GWI. It is not possible to accurately predict the number of GWI cases associated with this interaction. A very speculative estimate, based on our results, would rely on our observation that among all veterans in our sample who carried "at risk" BChE genotypes and also used PB during the war, $80 \%$ became GWI cases, constituting $9 \%$ of all cases in our study. If, overall, $9 \%$ of the 175,000-233,000 U.S. Gulf War veterans with GWI $[2,4,20]$ became ill as a result of an interaction between $\mathrm{PB}$ use and BChE genotype, an upper limit of 16,00021,000 affected veterans might be inferred. This estimate is tempered by uncertainties surrounding the diversity of 
exposures encountered by veterans in theater and additional genetic factors that potentially contributed to veterans' risk of developing GWI.

Our study had several limitations. Most importantly, our sample was only large enough to include 28 veterans with the less common $\mathrm{BChE}$ genotypes, disallowing a detailed assessment of the risk associated with individual genotypes, or in-depth multivariable assessment of all exposures in this subgroup. In this relatively small subgroup, the confidence interval for the observed association was wide, although the point estimate was extremely high $(\mathrm{OR}=40.0)$ and statistically significant. It is doubtful that an association of this magnitude would be an artifact of confounding by another exposure, especially since other potentially cholinergic exposures did not significantly interact with BChE genotype in our sample.

Additional limitations, common to other Gulf War studies, include our use of self-reported symptoms and deployment exposures, the only methods currently available to assess GWI and most aspects of Gulf War deployment. Usual concerns related to recall bias as an explanation for exposure-illness associations in Gulf War studies are less a concern for our findings, however, which relied on objective laboratory measures of both $\mathrm{BChE}$ genotype and activity. Veterans were unaware of their BChE genotype in reporting both symptoms and exposures, and did not report $\mathrm{PB}$ use differentially by genotype.

An important strength of our study is the sample, drawn randomly from a defined population. This provides confidence that our findings are more likely to be comparable to the larger Gulf War veteran population than findings from registry or clinical samples. Our results also indicate that use of the Kansas GWI case definition to determine case status was a strength. The Kansas GWI criteria appear to define a profile of symptomatic illness that is more specific to service in the 1991 Gulf War than other case definitions in use [1,21].

Overall, our finding of a significant interaction between $\mathrm{PB}$ use and $\mathrm{BChE}$ genotype in the risk for GWI is provocative, and possibly of great importance. If corroborated, it indicates that susceptible military personnel should not take PB, just as some individuals are currently not given succinylcholine when a genetic deficiency of BChE is suspected. This potentially has far reaching implications for U.S. military policy, which currently directs prophylactic use of $\mathrm{PB}$ as a protective measure for troops who are at risk for exposure to the nerve agent soman [60].

\section{Conclusions}

The specific causes and biological nature of Gulf War illness have yet to be adequately characterized. Our results illustrate complexities inherent in identifying either genetic factors or wartime exposures as risk factors for GWI and the need to assess both. Findings from this and related studies indicate that the long-sought "smoking gun" pointing to the cause of GWI may differ for different subgroups of veterans. Certainly, the magnitude of the association of GWI with the gene-exposure interaction identified here, if replicated in other groups, indicates that PB is a strong "smoking gun" candidate for the subgroup of Gulf War veterans with identified $\mathrm{BChE}$ genotypes.

\section{Abbreviations}

AChE: Acetylcholinesterase; BChE: Butyrylcholinesterase; BChE-LCV: Butyrylcholinesterase-less common variants subgroup;

Cl: Confidence interval; CDC: U.S. Centers for Disease Control and Prevention; DOD: U.S. Department of Defense; GWI: Gulf War illness; OR: Odds ratio; PB: Pyridostigmine bromide; PON1: Paraoxonase; SD: Standard deviation.

\section{Competing interests}

All authors declare they have no competing interests.

\section{Authors' contributions}

LS contributed to study design and had primary responsibility for subject screening, data analyses and drafting the manuscript. OL was responsible for all laboratory analyses. MMG contributed to study design, data collection, and data management. MRC contributed to study design, data collection, and was Co-PI on the parent project. AS had primary responsibility for study design and data collection and was PI on the parent project. All authors assisted in preparing the manuscript and read and approved the final manuscript.

\section{Authors' information}

Mary R Cook is currently retired.

\section{Acknowledgements}

Work for this project was performed at Midwest Research Institute (MRI; currently MRIGlobal), Kansas City, MO, the Eppley Institute at the University of Nebraska Medical Center, Omaha, NE, and Baylor Institute of Biomedical Studies, Waco, TX. This study was supported by the U.S. Army Medical Research and Materiel Command under contract number DAMD17-00C-0018 (to AS). AS, MMG, and MRC were employed by MRI (currently MRIGlobal), Kansas City, MO, at the time of the study. The authors thank the veterans who participated in the study and the Kansas Commission on Veterans Affairs.

\section{Additional notation pertaining to funding agency}

The views, opinions, and findings contained herein are those of the authors and should not be construed as an official Department of the Army position, policy, or decision unless so designated by other documentation. In the conduct of this research, the investigators adhered to the policies regarding the protection of human studies as prescribed by 45 CFR 46 and 32 CFR 219 (Protection of Human Subjects).

\section{Author details}

'Veterans Health Research Program, Baylor University Institute of Biomedical Studies, One Bear Place \# 97261, Waco, TX 76798, USA. ${ }^{2}$ The Eppley Institute, University of Nebraska Medical Center, Omaha, NE 68198, USA. ${ }^{3}$ Department of Biomedical and Health Informatics, University of Missouri-Kansas City School of Medicine, Kansas City, MO 64108, USA. ${ }^{4}$ MRIGlobal, Kansas City, MO 64110, USA. ${ }^{5}$ 3049D Trevor House Drive, Oakton, VA 22124, USA.

Received: 20 October 2014 Accepted: 17 December 2014 Published: 9 January 2015 


\section{References}

1. Steele L. Prevalence and patterns of Gulf War illness in Kansas veterans: association of symptoms with characteristics of person, place, and time of military service. Am J Epidemiol. 2000;152:992-1002.

2. Research Advisory Committee on Gulf War Veterans' Illnesses. Gulf War Illness and the Health of Gulf War Veterans. Washington, DC: U.S. Government Printing Office; 2008.

3. Kang HK, Li B, Mahan CM, Eisen SA, Engel CC. Health of US veterans of 1991Gulf War: a follow-up survey in 10 years. J Occup Environ Med. 2009:51:401-10.

4. Institute of Medicine (IOM). Gulf War and Health: Volume 8- Health Effects of Serving in the Gulf War. Washington, DC: National Academy Press; 2010

5. Ozakinci G, Hallman WK, Kipen HM. Persistence of symptoms in veterans of the First Gulf War: 5-year follow-up. Environ Health Perspect. 2006;114:1553-7.

6. Kang HK. Reported unexplained multisymptom illness among veterans who participated in the VA longitudinal health study of Gulf War era veterans. Presented at: Meeting of the Research Advisory Committee on Gulf War Veterans' Illnesses. Washington, D.C:; 2005. [http://www.va.gov/RAC-GWVI/docs/ Minutes_and_Agendas/Minutes_Sep2005_AppendixA_Presentation19.pdf]

7. Chao LL, Abadjian L, Hlavin J, Meyerhoff DJ, Weiner MW. Effects of low-level sarin and cyclosarin exposure and Gulf War Illness on brain structure andfunction: a study at 4 T. Neurotoxicology. 2011;32:814-22.

8. Rayhan RU, Stevens BW, Timbol CR, Adewuyi O, Walitt B, VanMeter JW, et al. Increased brain white matter axial diffusivity associated with fatigue, pain and hyperalgesia in Gulf War illness. PLoS One. 2013;8:e58493.

9. Sullivan K, Krengel M, Proctor SP, Devine S, Heeren T, White RF. Cognitive functioning in treatment-seeking Gulf War veterans: pyridostigmine bromide use and PTSD. J Psychopathol Behav Assess. 2003;25:95-103.

10. Toomey R, Alpern R, Vasterling JJ, Baker DG, Reda DJ, Lyons MJ, et al. Neuropsychological functioning of U.S. Gulf War veterans 10 years after the war. J Int Neuropsychol Soc. 2009:15:717-29.

11. Haley RW, Vongpatanasin W, Wolfe Gl, Bryan WW, Armitage R, Hoffman RF, et al. Blunted circadian variation in autonomic regulation of sinus node function in veterans with Gulf War syndrome. Am J Med. 2004;117:469-78.

12. Stein PK, Domitrovich PP, Ambrose K, Lyden A, Fine M, Gracely RH, et al. Sex effects on heart rate variability in fibromyalgia and Gulf War illness. Arthritis Rheum. 2004;51:700-8.

13. Haley RW, Charuvastra E, Shell WE, Buhner DM, Marshall WW, Biggs MM, et al. Cholinergic autonomic dysfunction in veterans with Gulf War illness: confirmation in a population-based sample. JAMA Neurol. 2013;70:191-200.

14. Zhang Q, Zhou XD, Denny T, Ottenweller JE, Lange G, LaManca JJ, et al. Changes in immune parameters seen in Gulf War veterans but not in civilians with chronic fatigue syndrome. Clin Diagn Lab Immunol. 1999;6:6-13.

15. Vojdani A, Thrasher JD. Cellular and humoral immune abnormalities in Gulf War veterans. Environ Health Perspect. 2004;112:840-6.

16. Whistler T, Fletcher MA, Lonergan W, Zeng XR, Lin JM, Lapierriere A, et al. Impaired immune function in Gulf War Illness. BMC Med Genomics. 2009;2:12.

17. Broderick G, Ben-Hamo R, Vashishtha S, Efroni S, Nathanson L, Barnes Z, et al. Altered immune pathway activity under exercise challenge in Gulf War IIIness: an exploratory analysis. Brain Behav Immun. 2013;28:159-69.

18. Golier JA, Schmeidler J, Legge J, Yehuda R. Enhanced cortisol suppression to dexamethasone associated with Gulf War deployment. Psychoneuroendocrinology. 2006;31:1181-9.

19. Golier JA, Schmeidler J, Legge J, Yehuda R. Twenty-four hour plasma cortisol and adrenocorticotropic hormone in Gulf War veterans: relationships to posttraumatic stress disorder and health symptoms. Biol Psychiatry. 2007;62:1175-8.

20. Research Advisory Committee on Gulf War Veterans' Illnesses. Gulf War Illness and the Health of Gulf War Veterans: Research Update and Recommendations, 2009-2013. Washington, DC: U.S. Government Printing Office; 2014

21. Steele L, Sastre A, Gerkovich MM, Cook MR. Complex factors in the etiology of Gulf War illness: wartime exposures and risk factors differ in veteran subgroups. Environ Health Perspect. 2012;120:112-8.

22. Fricker Jr RD, Reardon E, Spektor DM, Cotton SK, Hawes-Dawson J, Pace JE, et al. Pesticide Use During the Gulf War: A Survey of Gulf War Veterans. Arlington, VA: National Defense Research Institute (RAND); 2000.

23. U.S. Department of Defense. Environmental Exposure Report: Pesticides Final Repor. Washington, DC: Office of the Special Assistant to the
Undersecretary of Defense for Gulf War Illnesses Medical Readiness and Military Deployments; 2003

24. U.S. Department of Defense. Case Narrative: U.S. Demolition Operations at Khamasiyah, Final Report. Washington, DC: Office of the Special Assistant to the Undersecretary of Defense for Gulf War Illnesses Medical Readiness and Military Deployments; 2002

25. Cherry N, Creed F, Silman A, Dunn G, Baxter D, Smedley J, et al. Health and exposures of United Kingdom Gulf war veterans. Part II: the relation of health to exposure. Occup Environ Med. 2001;58:299-306.

26. Wolfe J, Proctor SP, Erickson DJ, Hu H. Risk factors for multisymptom illness in US Army veterans of the Gulf War. J Occup Environ Med. 2002;44:271-81.

27. Nisenbaum R, Barrett DH, Reyes $M$, Reeves WC. Deployment stressors and a chronic multisymptom illness among Gulf War veterans. J Nerv Ment Dis. 2000;188:259-66

28. Lockridge O, Masson P. Pesticides and susceptible populations: people with butyrylcholinesterase genetic variants may be at risk. Neurotoxicology. 2000;21:113-26.

29. Gatke MR, Viby-Mogensen J, Ostergaard D, Bundgaard JR. Response to mivacurium in patients carrying the $k$ variant in the butyrylcholinesterase gene. Anesthesiology. 2005;102:503-8

30. Lockridge $\mathrm{O}$. Genetic variants of human serum cholinesterase influence metabolism of the muscle relaxant succinylcholine. Pharmacol Ther. 1990:47:35-60

31. Loewenstein-Lichtenstein Y, Schwarz M, Glick D, Norgaard-Pedersen B, Zakut $\mathrm{H}$, Soreq $\mathrm{H}$. Genetic predisposition to adverse consequences of anticholinesterases in "atypical" BCHE carriers. Nat Med. 1995;1:1082-5.

32. Fukuda K, Nisenbaum R, Stewart G, Thompson WW, Robin L, Washko RM, et al. Chronic multisymptom illness affecting Air Force veterans of the Gulf War. JAMA. 1998:280:981-8.

33. Bartels CF, Jensen FS, Lockridge $O$, van der Spek AF, Rubinstein HM Lubrano T, et al. DNA mutation associated with the human butyrylcholinesterase K-variant and its linkage to the atypical variant mutation and other polymorphic sites. Am J Hum Genet. 1992;50:1086-103.

34. Bartels CF, James K, La Du BN. DNA mutations associated with the human butyrylcholinesterase J-variant. Am J Hum Genet. 1992;50:1104-14.

35. Jensen FS, Nielsen LR, Schwartz M. Detection of the plasma cholinesterase $K$ variant by PCR using an amplification-created restriction site. Hum Hered. 1996:46:26-31.

36. Nogueira CP, Bartels CF, McGuire MC, Adkins S, Lubrano T, Rubinstein HM, et al. Identification of two different point mutations associated with the fluoride-resistant phenotype for human butyrylcholinesterase. Am J Hum Genet. 1992;51:821-8.

37. Sudo K, Maekawa M, Akizuki S, Magara T, Ogasawara H, Tanaka T. Human butyrylcholinesterase L330I mutation belongs to a fluoride-resistant gene, by expression in human fetal kidney cells. Biochem Biophys Res Commun. 1997;240:372-5.

38. McGuire MC, Nogueira CP, Bartels CF, Lightstone H, Hajra A, Van der Spek $A F$, et al. Identification of the structural mutation responsible for the dibucaine-resistant (atypical) variant form of human serum cholinesterase. Proc Natl Acad Sci U S A. 1989;86:953-7.

39. SAS Institute Inc. SAS Statistical Software, Version 9.2. Cary, NC: SAS Institute; 2009

40. Lepage L, Schiele F, Gueguen R, Siest G. Total cholinesterase in plasma: biological variations and reference limits. Clin Chem. 1985;31:546-50.

41. Furlong CE, Li WF, Richter RJ, Shih DM, Lusis AJ, Alleva E, et al. Genetic and temporal determinants of pesticide sensitivity: role of paraoxonase (PON1). Neurotoxicology. 2000;21:91-100

42. Li B, Sedlacek M, Manoharan I, Boopathy R, Duysen EG, Masson P, et al. Butyrylcholinesterase, paraoxonase, and albumin esterase, but not carboxylesterase, are present in human plasma. Biochem Pharmacol. 2005:70:1673-84.

43. Furlong CE. PON1 status and neurologic symptom complexes in Gulf War veterans. Genome Res. 2000;10:153-5.

44. Kamel F, Hoppin JA. Association of pesticide exposure with neurologic dysfunction and disease. Environ Health Perspect. 2004;112:950-8.

45. Lockridge O. Butyrylcholinesterase Genetic Variants in Persons with Gulf War Illness. Fort Detrick, MD: U.S. Army Medical Research and Materiel Command; 1999 [http://www.gulflink.osd.mil/medsearch/GeneticStudies/ DoD60.shtml]

46. Haley RW, Billecke S, La Du BN. Association of low PON1 type Q (type A) arylesterase activity with neurologic symptom complexes in Gulf War veterans. Toxicol Appl Pharmacol. 1999;157:227-33. 
47. Concato J, Aslan M, Palmisano MM, Doebbeling CC, Peduzzi P, Ofek K, et al. Acetylcholinesterase activity in veterans of the first Gulf War. J Investig Med. 2007:55:360-7.

48. Mackness B, Durrington PN, Mackness MI. Low paraoxonase in Persian Gulf War Veterans self-reporting Gulf War Syndrome. Biochem Biophys Res Commun. 2000;276:729-33.

49. Hotopf M, Mackness MI, Nikolaou V, Collier DA, Curtis C, David A, et al. Paraoxonase in Persian Gulf War veterans. J Occup Environ Med. 2003:45:668-75.

50. Fontoura-da-Silva SE, Chautard-Freire-Maia EA. Butyrylcholinesterase variants (BCHE and CHE2 Loci) associated with erythrocyte acetylcholinesterase inhibition in farmers exposed to pesticides. Hum Hered. 1996;46:142-7.

51. Howard TD, Hsu FC, Grzywacz JG, Chen H, Quandt SA, Vallejos QM, et al. Evaluation of candidate genes for cholinesterase activity in farmworkers exposed to organophosphorus pesticides: association of single nucleotide polymorphisms in BCHE. Environ Health Perspect. 2010;118:1395-9.

52. Abou-Donia MB, Dechkovskaia AM, Goldstein LB, Abdel-Rahman A, Bullman SL, Khan WA. Co-exposure to pyridostigmine bromide, DEET, and/or permethrin causes sensorimotor deficit and alterations in brain acetylcholinesterase activity. Pharmacol Biochem Behav. 2004;77:753-62.

53. Somani SM, Husain K, Asha T, Helfert R. Interactive and delayed effects of pyridostigmine and physical stress on biochemical and histological changes in peripheral tissues of mice. J Appl Toxicol. 2000;20:327-34.

54. Beck KD, Zhu G, Beldowicz D, Brennan FX, Ottenweller JE, Moldow RL, et al. Central nervous system effects from a peripherally acting cholinesterase inhibiting agent: interaction with stress or genetics. Ann N Y Acad Sci. 2001;933:310-4.

55. Servatius RJ, Ottenweller JE, Beldowicz D, Guo W, Zhu G, Natelson BH. Persistently exaggerated startle responses in rats treated with pyridostigmine bromide. J Pharmacol Exp Ther. 1998;287:1020-8.

56. Giacobini E. Cholinesterase inhibitors: new roles and therapeutic alternatives. Pharmacol Res. 2004;50:433-40.

57. Hartmann J, Kiewert C, Duysen EG, Lockridge O, Greig NH, Klein J. Excessive hippocampal acetylcholine levels in acetylcholinesterase-deficient mice are moderated by butyrylcholinesterase activity. J Neurochem. 2007;100:1421-9.

58. Mesulam MM, Guillozet A, Shaw P, Levey A, Duysen EG, Lockridge O. Acetylcholinesterase knockouts establish central cholinergic pathways and can use butyrylcholinesterase to hydrolyze acetylcholine. Neuroscience. 2002:110:627-39.

59. Spencer PS, McCauley LA, Lapidus JA, Lasarev M, Joos SK, Storzbach D. Self-reported exposures and their association with unexplained illness in a population-based case-control study of Gulf War veterans. J Occup Environ Med. 2001;43:1041-56.

60. U.S. Food and Drug Administration. Pyridostigmine Bromide Information Page. [http://www.fda.gov/Drugs/EmergencyPreparedness/Bioterrorismand DrugPreparedness/ucm130341.htm]

doi:10.1186/1476-069X-14-4

Cite this article as: Steele et al:: Butyrylcholinesterase genotype and enzyme activity in relation to Gulf War illness: preliminary evidence of gene-exposure interaction from a case-control study of 1991 Gulf War veterans. Environmental Health 2015 14:4.

\section{Submit your next manuscript to BioMed Central and take full advantage of:}

- Convenient online submission

- Thorough peer review

- No space constraints or color figure charges

- Immediate publication on acceptance

- Inclusion in PubMed, CAS, Scopus and Google Scholar

- Research which is freely available for redistribution 